September 2001

\title{
Impact of computer training on professional library activities in Pakistan
}

\author{
Ashraf Sharif \\ Aga Khan University, ashraf.sharif@aku.edu \\ Khalid Mahmood \\ University of the Punjab
}

Follow this and additional works at: http://ecommons.aku.edu/libraries

Part of the Library and Information Science Commons

\section{Recommended Citation}

Sharif, A., Mahmood, K. (2001). Impact of computer training on professional library activities in Pakistan. Information Development, 17(3), 173-177.

Available at: http://ecommons.aku.edu/libraries/2 


\section{Impact of Computer Training on Professional Library Activities in Pakistan}

The Pakistan Library Association's Computer Training Center in Lahore has revolutionized the library and information science field in Pakistan.

\section{Ashraf Sharif and Khalid Mahmood}

\section{INTRODUCTION}

What is most lacking in the widespread use of computers in libraries and information centres is not the capability of computers or the availability of necessary software, but the right kind of personnel in implementing computer application projects in libraries. ${ }^{1}$ The Pakistan Library Association's Computer Training Center in Lahore is the only source of that kind of computer application projects for working librarians and students of two library schools in the Punjab (the most populous province of Pakistan). This centre was established in 1992 as a result of various meetings and discussions with the authorities of a variety of institutions. The offer by the Directorate of Public Libraries of the Punjab to provide the housing facility for the centre was accepted. The Secretary of the Punjab Library Foundation and the Director General of Public Libraries promised to provide a grant of PKR 100,000 to the computer centre. The Netherlands Library Development Project - Pakistan (NLDP-P) provided all initial equipment and costs to set up the centre. The Pakistan Library Association agreed to work as steering agency of the center. ${ }^{2}$ The centre was inaugurated by the then Punjab Minister of Education and the first course started on 2 November $1992 .{ }^{3}$ Since

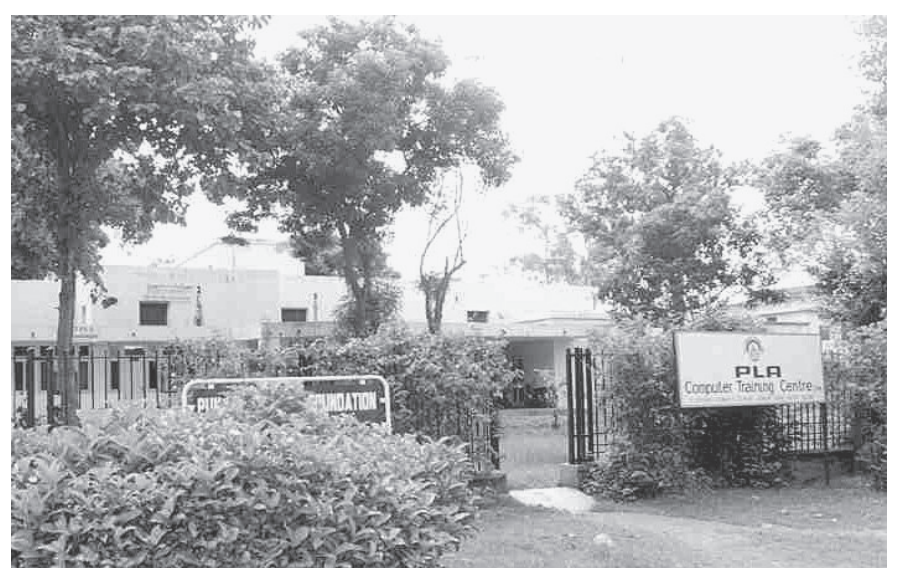

Figure 1. The Pakistan Library Association's Computer Training Centre, Labore. its founding, the centre has been playing a very vital role in providing training facilities in the field of library automation. The centre was initially provided with eleven IBM-compatible computers, three printers, a photocopying machine and an overhead projector. The centre is working on no-profit noloss basis. It has revolutionized the library and information science field in Pakistan.

Administratively, there are three functionaries of the centre ${ }^{4}$ :

1. the Managing Committee

2. the Programme Committee

3. the Manager.

Overall advice and supervision is the responsibility of the Managing Committee, which works as an independent governing body. Representatives from regional library associations are members of the Managing Committee. The Programme Committee comprises course instructors, the Manager and the Deputy Manager. It recommends the course contents and other academic programmes of the centre. The Manager works as secretary of the Managing Committee and convenor of the Programme Committee and administers the day-to-day routine and operations of the centre. Hardware and classroom facilities are sufficient to accommodate twenty participants at a time. There are ten personal computers for participants and one for the instructor. Two participants share one computer in the classroom-cum-lab.

By the end of 1999, twenty-four courses had been conducted at PLA-CTC. These included sixteen courses for the Certificate in Library Automation (CLA) as a regular core course. Table 1 shows the history of the CLA and the contents of the various courses. The remaining eight courses were exceptional. Some were offered as advancement on the core courses, and were organized specially for the centre's alumni. Some were offered only for students of the Department of Library and Information Science, University of the Punjab, Lahore. The courses have been designed keeping in view the market needs of working librarians and students of library schools.

\section{OBJECTIVES OF THE STUDY}

This study had the following major objectives:

- to determine the impact of the Certificate in Library Automation (CLA) on librarianship in Pakistan

- to examine the computer use pattern of the CLA holders

- to identify the specific areas in which Pakistan Library Association's Computer Training Center (PLA-CTC) needs improvement.

\section{METHODOLOGY}

The survey method was used for this study. A semi-structured questionnaire, containing eleven questions, was administered in order to collect the data. All but two questions were closed. To collect the addresses of the alumni, the office records of the PLA-CTC were used. It was decided that persons having at least one-year postgraduate diploma in library science or library and information science should be included in the 


\begin{tabular}{|c|c|c|c|c|c|c|c|c|}
\hline CLANo. & $\begin{array}{l}\text { Starting } \\
\text { Date }\end{array}$ & Duration & $\begin{array}{l}\text { Operating } \\
\text { System }\end{array}$ & $\begin{array}{l}\text { Word } \\
\text { Processor }\end{array}$ & Spread-sheet & Database & $\begin{array}{l}\text { Library } \\
\text { Software }\end{array}$ & Other \\
\hline 1 & 2-11-1992 & 18 weeks & DOS & Word 5.5 & Lotus123 & DBIII+ & ISIS & \\
\hline 2 & $15-6-1993$ & 10 weeks & DOS & WP5 & QPro & DBIII+ & ISIS & \\
\hline 3 & $6-11-1993$ & 16 weeks & DOS & WP5 & QPro & DBIII+ & ISIS & \\
\hline 4 & 01-3-1994 & 16 weeks & DOS & WP5 & QPro & DBIII+ & ISIS & \\
\hline 5 & $11-9-1994$ & 16 weeks & DOS & WP5 & QPro & DBIII+ & ISIS & \\
\hline 6 & 18-6-1995 & 10 weeks & DOS & WP5.1 & QPro & FoxPro & ISIS & \\
\hline 7 & $1-10-1995$ & 16 weeks & DOS & Word-6 & QPro & FoxPro & ISIS+LAMP & \\
\hline 8 & $16-6-1996$ & 10 weeks & DOS & Word-6 & QPro & FoxPro & ISIS+LAMP & \\
\hline 9 & $8-12-1996$ & 16 weeks & DOS & Word-6 & QPro & FoxPro & ISIS+LAMP & \\
\hline 10 & $16-6-1997$ & 10 weeks & Win 3.1 & Word-6 & QPro & FoxPro & ISIS+LAMP & \\
\hline 11 & $6-10-1997$ & 10 weeks & Win 3.1 & Word-6 & Excel & FoxPro & ISIS+LAMP & \\
\hline 12 & $22-6-1998$ & 10 weeks & Win 3.1 & Word-6 & Excel & FoxPro & ISIS+LAMP & \\
\hline 13 & $2-11-1998$ & 10 weeks & Win 95 & Word-97 & Excel & FoxPro & ISIS+LAMP & \\
\hline 14 & $8-2-1999$ & 10 weeks & Win 95 & Word-97 & Excel & Access & ISIS+LAMP & Internet \\
\hline 15 & 14-6-1999 & 10 weeks & Win 95 & Word-97 & Excel & Access & ISIS+LAMP & Internet \\
\hline 16 & 27-9-1999 & 10 weeks & Win NT & Word-97 & Excel & Access & ISIS+LAMP & Internet \\
\hline
\end{tabular}

Table 1. Details of the CLA courses.

survey. More than 260 people successfully completed the CLA up to and including the sixteenth course in $1999 .^{5}$

The questionnaire was sent to 175 qualified certificate holders. Different methods were used to send the questionnaire. The most popular was by postal mail. Hand-delivered and email methods were also applied where the facilities were available. A date was fixed and the alumni were requested to send the questionnaire back within this date. A total of 82 usable questionnaires were received - a response rate of 47 percent. The Statistical Package for the Social Sciences (SPSS) was used to generate frequencies, percentages and cross-tabulation.

\section{DATA ANALYSIS AND DISCUSSION}

\section{Demographic Information on the Respondents}

The analysis of the results shows that most of the respondents were young, with a median age of 32 years. Table 2 shows that 45 percent of respondents were aged between 21 and 30 and a further 35 percent between 31 and 40 years of age. More than 80 percent of respondents were thus between 21 and 40 years of age. Of the remainder, 15 percent were aged between 41 and 50 and another 5 percent between 51 and 60. Male respondents accounted for 80 percent of respondents while only 20 percent were female.

Information received regarding the first professional library qualification (i.e., Diploma in Library Science) showed that the respondents obtained this qualification between 1968 and 1998 .

\begin{tabular}{|l|l|l|l|}
\hline Age in Years & Frequency & Percent & Cumulative Percent \\
\hline 21 to 30 & 37 & 45 & 45 \\
\hline 31 to 40 & 29 & 35 & 80 \\
\hline 41 to 50 & 12 & 15 & 95 \\
\hline 51 to 60 & 4 & 5 & 100 \\
\hline Total & $\mathbf{8 2}$ & 100 & \\
\hline
\end{tabular}

Table 2. Age of the respondents.

Data on the employment status of the respondents (Table 3) show that 78 of the total of 82 respondents ( 95 percent) were currently in employment, mainly in libraries of various kinds. Respondents working in college libraries accounted for 44 percent of all those in employment, followed by those working in special libraries (23 percent) and public libraries (18 percent). University libraries and other organizations (including the national library, schools of library and information science, training institute for computer science, and non-governmental organizations (NGOs) each accounted for 8 percent of the total.

Out of 78 working respondents, 64 percent were from the public sector while the other 36 percent were working in the private sector. Most respondents (78 percent) were working in Lahore, where the PLA Computer Training Center is located, 


\begin{tabular}{|l|l|c|c|}
\hline Rank & Type of Institution & Frequency & Percent \\
\hline 1 & College library & 34 & 44 \\
\hline 2 & Special library & 18 & 23 \\
\hline 3 & Public library & 14 & 18 \\
\hline 4 & University library & 6 & 8 \\
\hline 5 & Other & 6 & 8 \\
\hline & Total & 78 & 100 \\
\hline
\end{tabular}

Table 3. Type of institution.

while the remaining 22 percent were working either in other large cities of the country or abroad.

An analysis of the time elapsed between the respondents' obtaining their first professional library qualification and their completion of the Certificate in Library Automation (CLA) reveals that 63 percent obtained their CLA within four years of their first library qualification. At the other extreme, in three cases (4 percent) the time lag between the respondents' obtaining the two qualifications was 25 years or more.

\section{Computer Training Before and After CLA}

The respondents were asked to provide information on any other computer education they received either before or after attending the CLA course. Twenty-three respondents (28 percent) had attended other courses before participating in the CLA course. Most of these ( 83 percent) had attended only one other course, 13 percent had attended two courses, and 4 percent (one respondent) had attended three other courses.

Thirty respondents (37 percent) participated in other computer courses after attending the CLA course. Of these, 70 percent had attended one other course, 17 percent had attended two courses, 10 percent had attended three courses, and 4 percent (one respondent) had attended four other courses after completing the CLA.

A comparison of the responses on computer training before and after CLA reveals that thirteen (57 percent) of the twentythree respondents who had attended courses before CLA continued their training afterwards, while seventeen respondents began attending other courses for the first time after completing the CLA course.

An analysis of the responses from those who had received some computer training before the CLA reveals that had they taken courses in accounting, BASIC, C, CDS/ISIS, COBOL, Dbase, DOS, FORTRAN, FoxPro, Internet, LAMP, Lotus23, MS-Excel, networking, systems analysis and design, Windows and wordprocessing. The eighteen institutions providing these courses included the PLA Computer Training Center, the Lahore and Punjab University Library Science Alumni Association (PULSAA) and computer colleges in Lahore and other nearby cities.

Those who followed other computer training after the CLA course studied a wider variety of topics, including advanced CDS/ISIS, BASIC, C, CD-ROM technology, DOS, FoxPro, Inmagic, Internet, LAMP, Macintosh operating system,

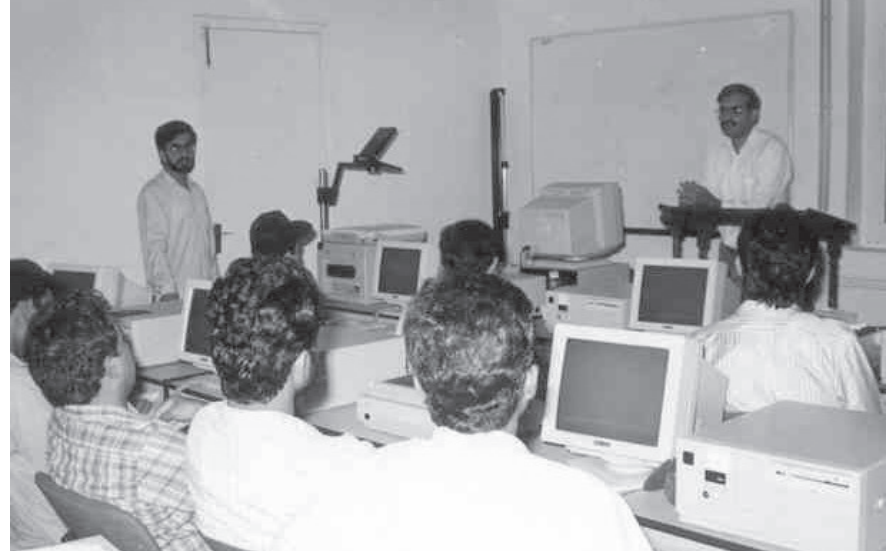

Figure 2. The session is on: the class of 1993.

MARC, MS-Access, MS-Excel, networking, Oracle, Photoshop, Powerpoint, Visual Basic, web development, Windows, WINISIS and wordprocessing. The twenty-three institutions from which these respondents received their further computer education included the PLA Computer Training Centers in Lahore and Islamabad, the Academy of Educational Planning and Management, Islamabad and other computer colleges in various cities of the country and abroad.

These data clearly show that the trend of getting computer education was accelerated in the respondents after they had attended the CLA course. After CLA, more respondents attended more computer courses, and studied a wider variety of subjects, than before the CLA. The PLA Computer Training Centres played a key role also in providing these other training opportunities.

\section{Impact of Computer Training on Job Seeking}

Respondents were asked whether or not their computer knowledge and skill helped them in getting a job or a better job after completing the CLA. Of the seventy-eight respondents in employment, seventy-seven (99 percent) provided information about this question. Two-thirds of all respondents said that their computer knowledge had been helpful in this regard; almost two-thirds of this group had not received any computer education prior to the CLA.

Analysis of the results reveals that all respondents working in 'other institutions', together with 83 percent of those working in special libraries, 79 percent of those in public libraries and 60 percent of those in college libraries said that their computer knowledge had helped them get a better job. In university libraries, on the other hand, only one of the six people responding to this question had found their computer knowledge helpful in this regard.

More than 75 percent of those who felt that their computer knowledge had helped them get a job had obtained their CLA within four years of obtaining their first professional qualification. This probably reflects the greater job mobility of younger professionals.

A further analysis of these data also reveals that all twentyfour respondents who were working in the private sector said 


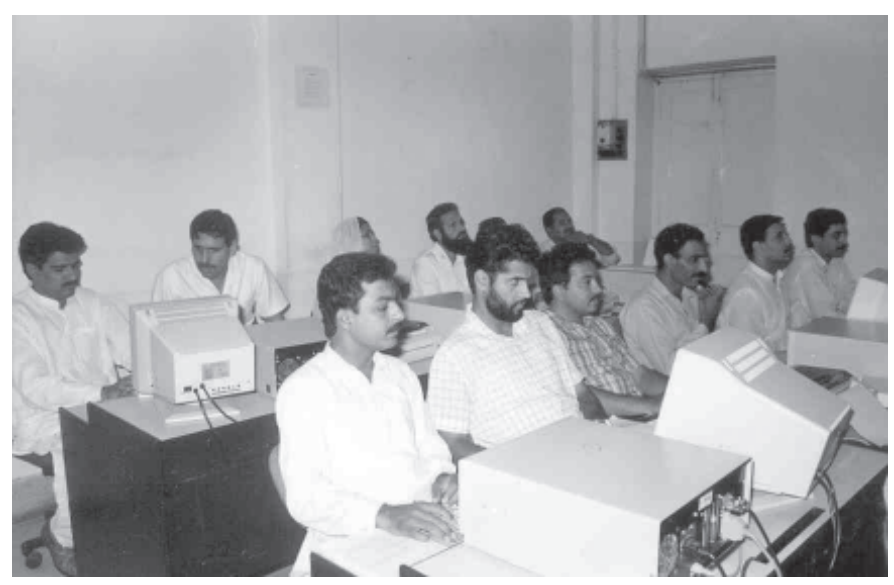

Figure 3. Another view of the class of 1993.

that their computer knowledge helped them get a better job. On the other hand, only twenty-six of the fifty respondents from the public sector had found this to be the case. The difference is probably due to the fact that job mobility in the public sector is lower than in the private sector.

\section{Computer Facility and Use}

Respondents were asked to provide information on computer facilities at their offices and homes and the frequency with which they use them. The results show that 72 percent of the total had computer facilities at their offices while 15 percent had such facilities at home. A substantial proportion of all respondents (62 percent) used computers on a daily basis. Another 18 percent said they seldom used a computer, and there were six persons ( 7 percent) who said they never used a computer. An analysis of the use of computers by type of institution shows that, in proportion to their numbers, respondents from public and special libraries and 'other' institutions used computers more frequently than those in university or college libraries. Similarly, respondents in the private sector used computers proportionately more frequently than those in the public sector.

\section{Participation in Library Automation Projects}

To see the impact of computer training on the professional activities of the respondents they were asked to provide information about their involvement in the automation process of their organizations. Fifty percent of the seventy respondents (85 percent of the total) to this question indicated that they played an active role in the automation process, while 17 percent said they felt comfortable in using computers and 14 percent had helped their institutions to start new automated services. Three respondents helped in designing commercial software for libraries. Despite the fact that 30 percent of respondents said that their libraries were not automated, this information clearly indicates that the computer knowledge of the respondents has helped a lot in the automation process of libraries in the country.

\section{Participation in other Automation Related Activities}

The survey revealed that many of the certificate holders of the PLA-CTC have utilized their computer knowledge in many other professional activities in addition to their daily work. Of the thirty three respondents (40 percent of the total) who reported such activity, two had written a total of three books on information technology in libraries, nine had published a total of thirty-three articles on library automation, sixteen had delivered a total of 747 lectures on information technology, and twenty-five had provided 131 consultancies on library automation to various institutions and organizations. Others had organized training courses on library automation, prepared bibliographies or helped computer science students in completing their assignments for developing library software packages. This information also shows that the certificate holders have exerted a great impact on the library profession with their computer knowledge.

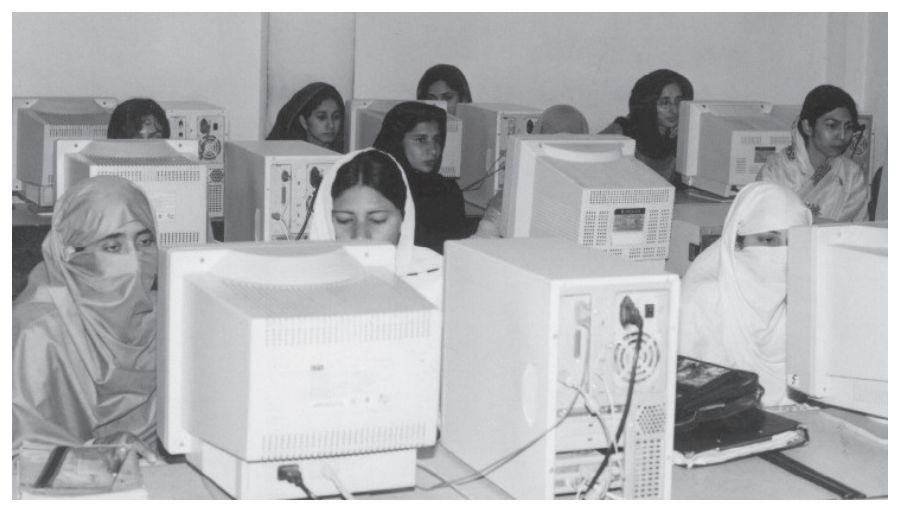

Figure 4. The librarians of tomorrow (class of 2001).

\section{Suggestions Regarding Further Courses}

The respondents were asked to suggest subjects or topics for further development of courses at the PLA Computer Training Center. They showed a keen interest in this matter and proposed a large variety of programmes or packages. Most of them recommended that the Center should offer advanced courses in library automation. Other topics suggested included computer languages, the Internet, other library software packages, web development, networking, and Oracle database management. It is interesting to note that some of the topics recommended by the respondents have already been offered by the Center. This reveals the flaws in the knowledge of some professionals about the activities of the Center.

\section{Suggestions for Improvement of CLA/PLA-CTC}

The respondents generously offered suggestions to improve the quality of courses at the PLA Computer Training Center. The major recommendations, in order of frequency, were as follows:

- The Center should enhance its hardware facilities. At least one terminal should be made available for each participant. 
- The duration of the courses should be extended.

- The Center should arrange seminars and meetings for librarians on various aspects of library automation.

- The participants feel difficulty in their nomination and fee payment from their employers. The Center should provide help in this regard.

- Hardware facilities at the Center should be made up-todate. The latest technology used in computer hardware should be adopted.

- Facilities for practice by the participants should be increased.

- The Center should organize an activity forum for its alumni.

- The Center should hire more competent teaching faculty.

- The Center should be involved in software development for libraries in Pakistan.

- The Centre's hardware laboratory should be open to its alumni for practice.

- The Center should focus its training activities on library software packages.

- The Center should arrange hostel facilities for participants from outside Lahore.

- The Center should try to get research and development projects on library automation.

- Courses for non-librarians may be started on a commercial basis.

- A certificate award ceremony should be organized regularly.

- The courses currently offered as a package in the form of CLA should also be offered separately.

\section{CONCLUSION}

It is evident from this study that it has been mostly comparatively young professional librarians, just after having obtained their professional library qualification, who have attended the basic computer course offered by the PLA Computer Training Center in Lahore. Most of them are working in Lahore but there are significant numbers in other cities. Their computer training contributed a lot to their success in getting new jobs. Most of the librarians surveyed have computer facilities in their offices and use them daily. After acquiring computer knowledge they have participated significantly in the automation process of their libraries. Many also utilized their computing skill in writing books, articles, delivering lectures and providing consultancy services. The alumni of the centre have many ideas for the improvement of the contents and quality of the courses. It is recommended that the PLA Computer Training Center should keep in close contact with its alumni to monitor and help in their automation related activities, and get feed-back on its training programmes.

\section{References}

1. Balakrishnan, M.R. Computers and their role in libraries. In: Ojha, D.C. (ed.), Computer applications in library and information science. Jodhpur, Scientific Publishers, 1995, p. 95.

2. Riaz, Bushra Almas. The PLA Computer Training Center, Lahore: a new era of library and information science education in Pakistan. In: Asghar, Muhammad, Afzal Haq Qarshi and Syed Jamil Ahmad Rizvi (eds), Hallmarks of library and information services in Pakistan. Lahore: PULSAA, 1993, p. 232.

3. Mahmood, Khalid. PLA Computer Training Center, Lahore: three years of success. PLA Journal, no. 19-20, October 1996-October 1997, 58-69.

4. PLA Computer Training Center. Handbook. Lahore. The Center, 1993.

5. PLA-CTC records.

\section{Abstract}

Report on a survey of alumni of the Pakistan Library Association's Computer Training Center in Lahore to determine the impact of the Certificate in Library Automation (CLA) on librarianship in Pakistan. The survey provided information on: the profile of the respondents; their participation in computer training before and after taking the CLA; the impact of their training on their success in job seeking; their access to and use of computers; their participation in library automation projects and other automation related activities; and suggestions regarding further courses and the improvement of the Training Centre. The results showed that the courses were attended mainly by comparatively young professional librarians, most of whom were working in Lahore. Their computer training contributed a lot to their success in getting new jobs. Most of them had access to computer facilities in their offices and use them daily, and have participated significantly in automation activities in their libraries. Many also applied their computing knowledge in writing books, articles, delivering lectures and providing consultancy services. Many suggestions were made for improving the courses.

Ashraf Sharif is Readers' Services Librarian, Lahore University of Management Sciences (LUMS), Opposite Sector 'U', Defense Housing Authority, Lahore Cantt., Pakistan. Email: mashraf@lums.edu.pk.

Khalid Mahmood is Lecturer, Department of Library and Information Science, University of the Punjab, Lahore, Pakistan. E-mail: mahmoodkhalid@hotmail.com. 